\title{
Additional Heart Sounds-Part 2 (Clicks, Opening Snap and More)
}

\author{
Lalita Nemani ${ }^{1}$ Ramya Pechetty ${ }^{2}$ \\ ${ }^{1}$ Department of Cardiology, Nizam's Institute of Medical Sciences, \\ Hyderabad, Telangana, India \\ 2Department of Cardiology, Apollo Hospitals, Jubilee Hills, \\ Hyderabad, Telangana, India \\ Ind J Car Dis Wom:2020;5:351-363
}

Address for correspondence Lalita Nemani, MD, DM, Department of Cardiology, Nizam's Institute of Medical Sciences, Hyderabad, Telangana, India (e-mail: drlalita775@gmail.com).
Abstract
Keywords
- ejection click
- nonejection clicks
- mitral valve prolapse
- opening snap
- pericardial friction rub
- Hammam's crunch
- prosthetic sounds

Systolic clicks are high-pitched sharp sounds. They are classified as ejection and nonejection clicks. Ejections clicks commonly occur at the aortic and pulmonary valve, while nonejection clicks occur at the mitral and tricuspid valve.

Opening snap is an additional sound heard in the diastole. It is described as an early diastolic, high-pitched sound, which is associated with opening of the mitral and/or tricuspid valve.

Pericardial knock is a high-pitched early diastolic sound, which is characteristic of constrictive pericarditis.

The opening and closing of prosthetic valves produce sounds which may vary in intensity and timing according to the type and design of the valve, patient's rhythm, and hemodynamic status.

\section{Systolic Clicks}

Systolic clicks are high-pitched sharp sounds. ${ }^{1-4}$ They are classified as ejection and nonejection clicks. Ejections clicks (ECs) commonly occur at the aortic and pulmonary valve, while non-ejection clicks occur at the mitral and tricuspid valve ( - Fig. 1).

Technique of auscultation and detection of systolic click: Clicks are best heard with the diaphragm of the stethoscope and are loudest at their respective auscultatory areas ( - Fig. 2 ).

They are identified as sharp additional sound in the systole by simultaneous auscultation of the heart and carotid artery palpation to rightly identify S1 and S2. They are further identified as early, mid, and late systolic clicks and evaluated in relation to dynamic maneuvers.

\section{Ejection Clicks (ECs)}

They are sharp high-pitched sounds heard in early systole just after the first heart sound ( - Fig. 3).

published online

December 23, 2020
DOI https://doi.org/

10.1055/s-0040-1722385.
ECs occur at the maximal opening of the semilunar valves. Being high frequency sounds, they are best heard with the diaphragm. ECs result from opening of the stenotic/diseased aortic and pulmonary valves or from normal valves in the presence of dilated aorta or pulmonary artery.

Types of ECs: ECs are classified as valvular or vascular.

Valvular clicks: They result from abnormal aortic and pulmonary valves.

Mechanism: Abrupt opening of aortic and pulmonary valves generate ECs. The abrupt halting movement of the diseased valves produces this audible sound ( - Fig. 4).

A. Aortic valvular click.

a. Valvular aortic stenosis (AS).

b. Congenital bicuspid aortic valve.

c. Congenital quadricuspid aortic valve as in truncus arteriosus.

B. Pulmonary valvular click.

a. Valvular pulmonary stenosis.

C2020. Women in Cardiology and Related Sciences.

This is an open access article published by Thieme under the terms of the Creative Commons Attribution-NonDerivative-NonCommercial-License, permitting copying and reproduction so long as the original work is given appropriate credit. Contents may not be used for commercial purposes, or adapted, remixed, transformed or built upon. (https://creativecommons.org/licenses/by-nc-nd/4.0/).

Thieme Medical and Scientific Publishers Pvt. Ltd. A-12, 2nd Floor, Sector 2, Noida-201301 UP, India 


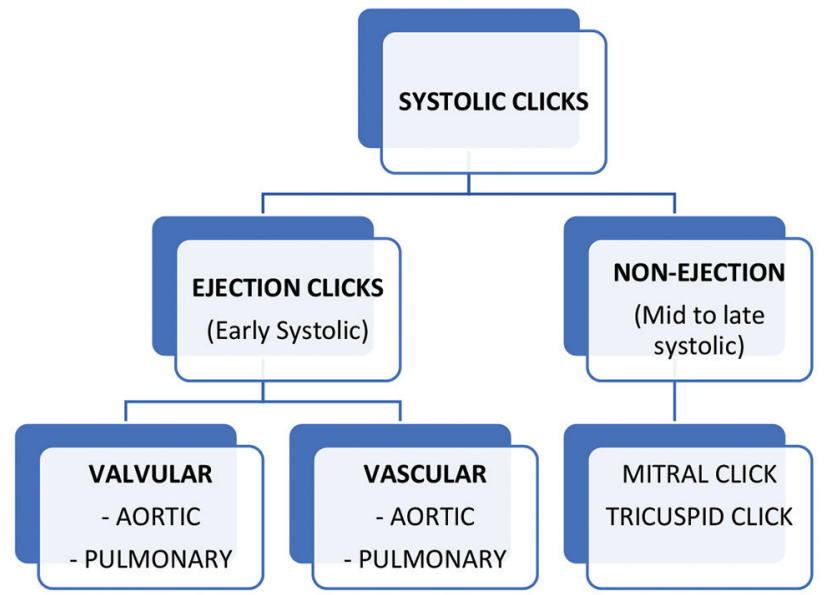

Fig. 1 Classification of systolic clicks.

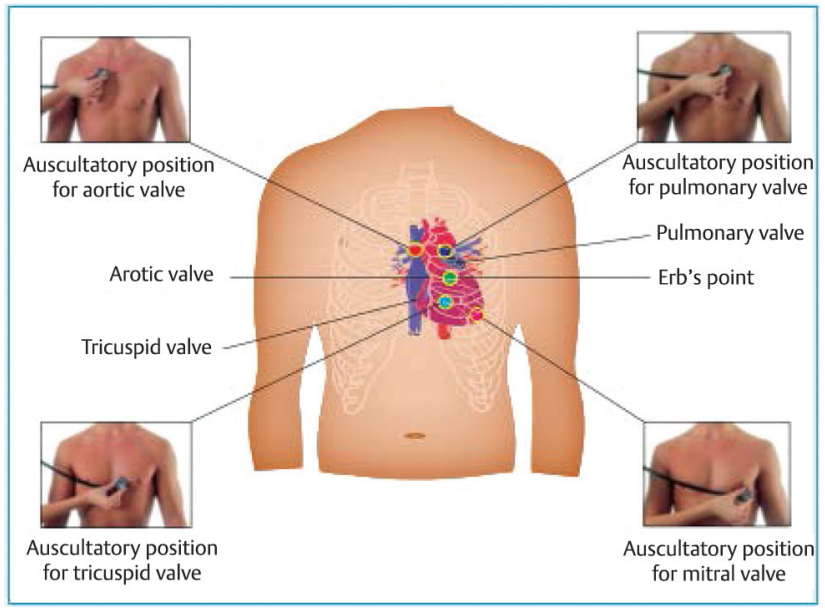

Fig. 2 Auscultation sites on precordium.

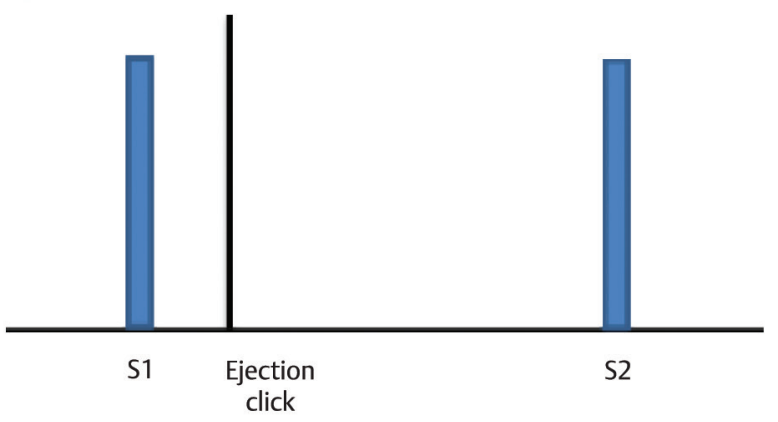

Fig. 3 Systolic ejection click.

Clinical characteristics of aortic and pulmonary valvular clicks are mentioned below (-Table $\mathbf{1}$ ).

\section{Clinical Significance}

\section{Ejection Click of Aortic Stenosis (AS)}

- Diagnostic of valvular AS and is absent in supravalvular or subvalvular AS.

- It corresponds to the notch in the upstroke of the aortic pressure tracing or the carotid pulse tracing (-Fig. 6).
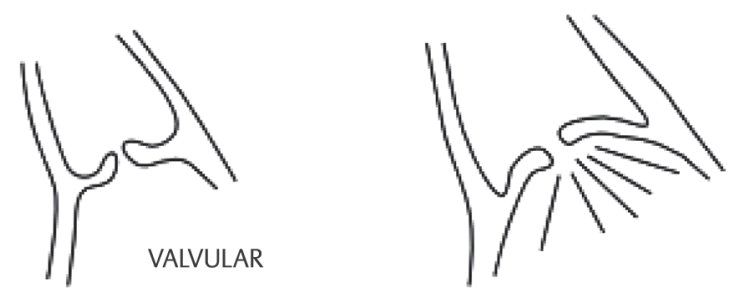

Fig. 4 Mechanism of valvular ejection click.

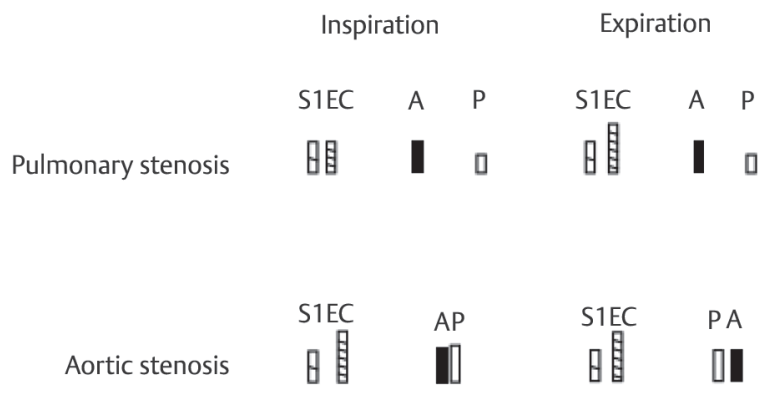

Fig. 5 Effect of respiration on pulmonary and aortic valvular click.

Table 1. Clinical characteristics of aortic and pulmonary valvular click

\begin{tabular}{|l|l|l|}
\hline & $\begin{array}{l}\text { Aortic valvular } \\
\text { click }\end{array}$ & Pulmonary valvular click \\
\hline $\begin{array}{l}\text { Site of best } \\
\text { audibility }\end{array}$ & $\begin{array}{l}\text { Widely heard } \\
\text { Best heard at the } \\
\text { apex followed by } \\
\text { right second inter- } \\
\text { coastal space }\end{array}$ & $\begin{array}{l}\text { Localized } \\
\text { Best heard in the second } \\
\text { left intercostal space }\end{array}$ \\
\hline $\begin{array}{l}\text { Respiration } \\
\text { (Fig. 5) }\end{array}$ & Not affected & $\begin{array}{l}\text { Decrease in intensity and } \\
\text { occurs early/ merge with } \\
\text { S1 in inspiration }\end{array}$ \\
\hline $\begin{array}{l}\text { Carotid } \\
\text { upstroke }\end{array}$ & $\begin{array}{l}\text { Immediately before } \\
\text { or coincident } \\
\text { with initial carotid } \\
\text { upstroke }\end{array}$ & $\begin{array}{l}\text { Usually before or with the } \\
\text { initial carotid upstroke, } \\
\text { however a delay in onset } \\
\text { favors pulmonary origin }\end{array}$ \\
\hline $\begin{array}{l}\text { Relation } \\
\text { with Q } \\
\text { wave on } \\
\text { ECG }\end{array}$ & $\begin{array}{l}\text { Occurs 120 to 140 } \\
\text { milliseconds after } \\
\text { onset of Q wave on } \\
\text { ECG }\end{array}$ & $\begin{array}{l}\text { Occurs } 90 \text { to 110 millisec- } \\
\text { onds after onset of Q wave } \\
\text { on ECG }\end{array}$ \\
\hline
\end{tabular}

This notch apparently results from maximal opening and abrupt deceleration of the flexibly stenotic aortic valve.

- Intensity of the sound decreases with calcification. Seen only with pliable valves and is absent in severe calcific AS.

- Calcification of the aortic valve is a rule beyond the age of 40 years. Hence, presence of aortic ejection click in adults suggests either mild AS or presence of congenital bicuspid aortic valve.

- Presence of an aortic EC in the child is diagnostic of congenital bicuspid aortic valve.

- Absence of other signs of AS in the presence of aortic EC strongly suggests the presence of bicuspid aortic valve. 
Ejection Click (EC) of Pulmonary Stenosis (PS) ${ }^{7,8}$

- Diagnostic of valvular PS.

- It is the only right-sided acoustic event that softens (diminishes) with inspiration.

- Mechanism of inspiratory decrease in the pulmonary EC.

- In PS, the right ventricle (RV) is stiff and hypertrophied.

- During inspiration, when more blood enters the RV, it fails to distend normally. As a result, the RV pressure increases, and exceeds that of the pulmonary artery pressure, which falls slightly. The pulmonary valve is partially open (domed or tensed position) prior to

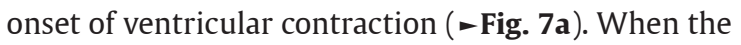
$\mathrm{RV}$ contracts, excursion of the partially opened pulmonary valve is reduced and therefore the EC is softer and occurs earlier.

- During expiration, venous return to the right heart is decreased. At the same time, the pulmonary artery pressure also rises slightly. As the pulmonary artery end-diastolic pressure exceeds the RV pressure, the pulmonary valve leaflets are in a closed or slack position ( - Fig. $\mathbf{7 b}$ ). With ventricular systole, the valve opens quickly and then abruptly halts, producing the ejection sound.

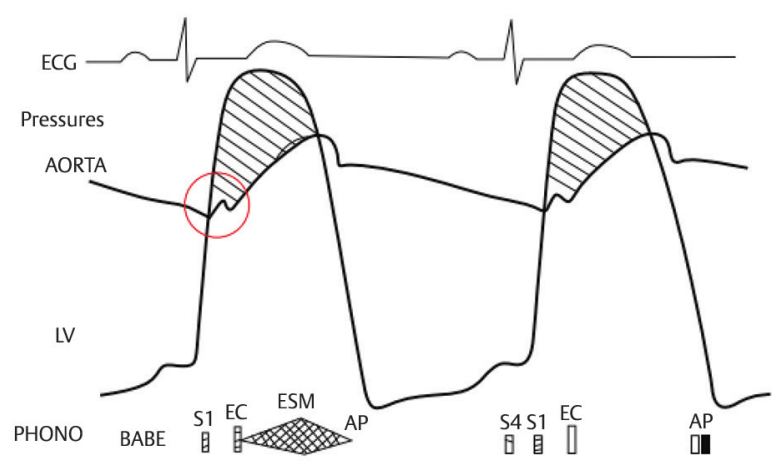

Fig. 6 Physiological basis of ejection click in aortic stenosis.
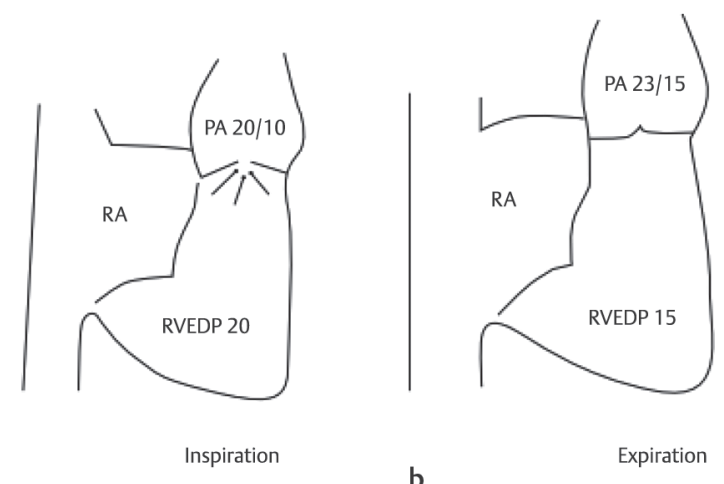

Fig. 7 (a and b) Respiratory variation of pulmonary ejection click.
The S1-pulmonary EC interval is directly related to RV isovolumic contraction time. With increasing severity of PS, the isovolumic systolic interval shortens resulting in early onset of EC.

- Mild-to-moderate PS-EC becomes soft and occurs earlier.

- Severe PS-the RV may become so stiff that a vigorous atrial contraction opens the pulmonary valve completely, producing a click in late diastole.

- Very severe PS-the EC fuses with S1 and may not be identified

Vascular clicks ${ }^{9}$ : They occur in the presence of normal aortic and pulmonary valves. They result from rapid distension of the dilated proximal aorta or pulmonary artery at the onset of ejection.

Mechanism: Vascular clicks result from increased pressure, increased flow, and dilatation of the great vessels ( $\mathbf{- F i g . ~ 8 ) . ~}$ Causes:

A. Aortic vascular click.

a. Systemic hypertension.

b. Aneurysm of the ascending aorta.

c. Aortic regurgitation.

d. Tetralogy of Fallot-anterior dilated aorta.

e. Anemia and thyrotoxicosis-hyperkinetic circulatory states.

B. Pulmonary vascular click.

a. Pulmonary hypertension.

b. Idiopathic dilatation of the pulmonary artery.

c. Left-to-right shunts. ${ }^{10}$

d. Hyperkinetic circulatory states.

Clinical characteristics of vascular and valvular clicks ${ }^{11}$ are shown in - Table 2.

Aortic vascular and valvular clicks can be identified, based on associated clinical features ( $\mathbf{- T a b l e} \mathbf{3}$ ).

Pulmonary clicks can be differentiated, based on respiratory variation and associated clinical features ( - Table 4 ).

\section{Significance}

Aortic vascular click is associated with aortic root dilation in the form of aortic sclerosis with tortuous aortic root, systemic hypertension, ascending aortic aneurysm and aortic regurgitation due to aortic root pathology.

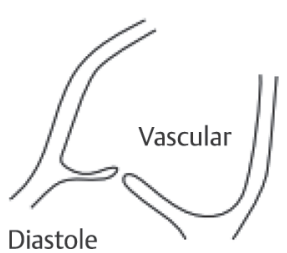

Fig. 8 Mechanism of vascular clicks. 
Table 2. Clinical characteristics of vascular and valvular clicks

\begin{tabular}{|l|l|l|}
\hline S2 intensity & Vascular clicks & Valvular clicks \\
\hline Split S2 & $\begin{array}{l}\text { Normal/close/ } \\
\text { single }\end{array}$ & $\begin{array}{l}\text { Normal or } \\
\text { diminished }\end{array}$ \\
\hline $\begin{array}{l}\text { Palpable artery } \\
\text { beyond valve }\end{array}$ & Palpable & impalpable \\
\hline
\end{tabular}

Table 3. Aortic vascular versus valvular click

\begin{tabular}{|c|c|c|}
\hline & Aortic vascular click & Aortic valvular click \\
\hline Etiology & $\begin{array}{l}\text { Normal aortic valve. } \\
\text { Dilated aortic root }\end{array}$ & $\begin{array}{l}\text { Stenotic aortic valve and } \\
\text { non-stenosed Bicuspid } \\
\text { aortic valve }\end{array}$ \\
\hline $\begin{array}{l}\text { Site of } \\
\text { best } \\
\text { audibility }\end{array}$ & $\begin{array}{l}\text { Best heard at the aortic } \\
\text { area (second right inter- } \\
\text { costal space). Poorly } \\
\text { transmitted to the apex }\end{array}$ & Best heard at the apex \\
\hline
\end{tabular}

Table 4. Pulmonary vascular versus valvular clicks

\begin{tabular}{|l|l|l|}
\hline & $\begin{array}{l}\text { Pulmonary } \\
\text { vascular click }\end{array}$ & $\begin{array}{l}\text { Pulmonary valvular } \\
\text { click }\end{array}$ \\
\hline Etiology & $\begin{array}{l}\text { Dilated main pul- } \\
\text { monary artery and } \\
\text { normal pulmonary } \\
\text { valve }\end{array}$ & Pulmonary stenosis \\
\hline Respiration & $\begin{array}{l}\text { No consistent res- } \\
\text { piratory variation }\end{array}$ & $\begin{array}{l}\text { Respiratory variation } \\
\text { seen. The ejection } \\
\text { click becomes softer } \\
\text { and occurs earlier with } \\
\text { inspiration }\end{array}$ \\
\hline
\end{tabular}

Pulmonary vascular click is associated with pulmonary hypertension and pulmonary arterial dilatation.

Differential diagnosis: ECs may be confused with a split S1 or a S4 followed by an early S1 ${ }^{11}$ ( Tables 5 and $\mathbf{6}$ ).

\section{Nonejection Sounds ${ }^{1-4}$}

High-frequency sounds are best heard with the diaphragm of the stethoscope, and usually occur much later after the first

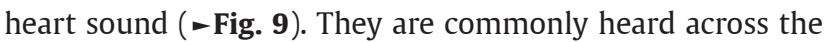
atrioventricular valves in prolapse (myxomatous degeneration) of the mitral and tricuspid valves.

Causes:

1. Mitral valve prolapse (MVP)

2. Tricuspid valve prolapse (TVP).

3. Ebstein's anomaly

4. Aneurysm of the membranous septum with ventricular septal defect (VSD).

Characteristic features:

- Sharp, high-frequency, click-like sound

- Heard best at the apex (MVP) or at the left lower sternal border (LLSB) TVP.

- Usually single, but may be multiple

- Heard in mid-to-late systole
Table 5. S1-EC versus split S1

\begin{tabular}{|l|l|l|}
\hline & S1-EC & Split S1 \\
\hline $\begin{array}{l}\text { Quality of } \\
\text { sounds }\end{array}$ & $\begin{array}{l}\text { Both are high-pitched } \\
\text { sounds }\end{array}$ & $\begin{array}{l}\text { Second sound (tricus- } \\
\text { pid sound) is a low- } \\
\text { pitch sound }\end{array}$ \\
\hline $\begin{array}{l}\text { Site of } \\
\text { audibility }\end{array}$ & $\begin{array}{l}\text { Best heard at the } \\
\text { base of the heart and } \\
\text { apex }\end{array}$ & $\begin{array}{l}\text { Best heard at the lower } \\
\text { sternal border }\end{array}$ \\
\hline Respiration & $\begin{array}{l}\text { No variation in case } \\
\text { of aortic ejection } \\
\text { click. Pulmonary } \\
\text { ejection click softens } \\
\text { with inspiration }\end{array}$ & $\begin{array}{l}\text { Tricuspid sound } \\
\text { becomes louder on } \\
\text { inspiration }\end{array}$ \\
\hline
\end{tabular}

Abbreviation: EC, ejection click.

Table 6. S1-EC versus S4 with early S1

\begin{tabular}{|l|l|l|}
\hline & S1-EC & S4-S1 \\
\hline $\begin{array}{l}\text { Quality of } \\
\text { sound }\end{array}$ & $\begin{array}{l}\text { High-pitched- } \\
\text { better heard } \\
\text { with diaphragm }\end{array}$ & $\begin{array}{l}\text { S4 is a low-pitched sound- } \\
\text { better heard with bell }\end{array}$ \\
\hline $\begin{array}{l}\text { Site of } \\
\text { audibility }\end{array}$ & $\begin{array}{l}\text { Best heard at } \\
\text { aortic area and } \\
\text { apex }\end{array}$ & Localized to the apex \\
\hline $\begin{array}{l}\text { Associated } \\
\text { features }\end{array}$ & - & $\begin{array}{l}\text { Associated with presystolic } \\
\text { impulse }\end{array}$ \\
\hline
\end{tabular}

Abbreviation: EC, ejection click.

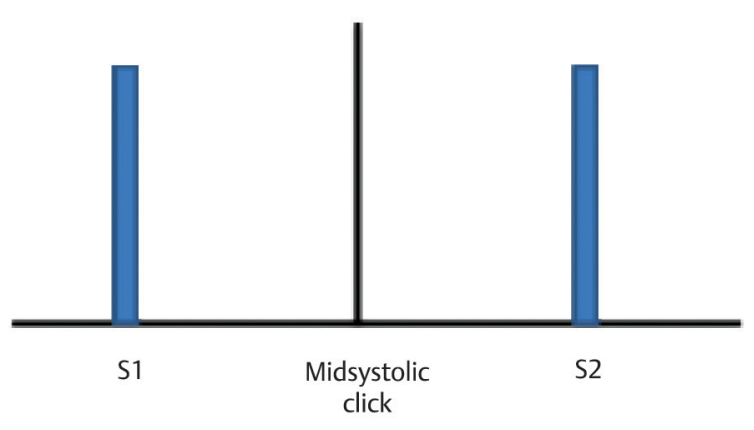

Fig. 9 Nonejection click/midsystolic clicks.

- Vary in timing with respiration, posture, and other dynamic maneuvers.

Systolic clicks in MVP12,13: Midsystolic click is a characteristic auscultatory finding of MVP. It is the result of sudden tensing of the mitral valve apparatus, as the leaflets prolapse into the left atrium in systole.

Mechanism: Normally, with the onset of ventricular systole, when the left ventricular (LV) pressure exceeds that of the left atrium, the prolapse of mitral leaflets into the left atrium is prevented by the mitral cusps, chordae tendineae, and papillary muscle contraction (mitral valve apparatus). In MVP, there is myxomatous degeneration and elongation of the mitral leaflets and chordae tendineae. The click results from sudden snapping/halting of the prolapsed mitral leaflets into left atrium after the onset of ventricular contraction. 
As different parts of the mitral leaflets prolapse at different times of systole, multiple clicks can be heard ( - Fig. 10).

The click is mobile, which means it varies in timing and loudness with change in ventricular volumes and contractility (-Table 7).

Prolapse does not occur immediately on the onset of ventricular systole. Prolapse starts when the LV size reaches a critical point and persists after that ( - Fig. 11). Click occurs at the onset of that prolapse, followed by the murmur, which persists throughout the systole.

Any maneuver that decreases the LV volume $(\downarrow)$ (-Fig. 12a) causes the prolapse to occurs earlier in systole and brings the click closer to S1. Decrease in LV volume is the result of the following:

Decreased impedance to LV outflow.

Decreased venous return.

Increased contractility.

Tachycardia.

Any maneuver that increases the LV volume () ( - Fig. 12b) causes the prolapse to occur latter and click is delayed. Increase in $\mathrm{LV}$ volume is seen in conditions of-

Increased impedance to $\mathrm{LV}$ outflow.

Increased venous return.

Increased contractility.

Bradycardia.

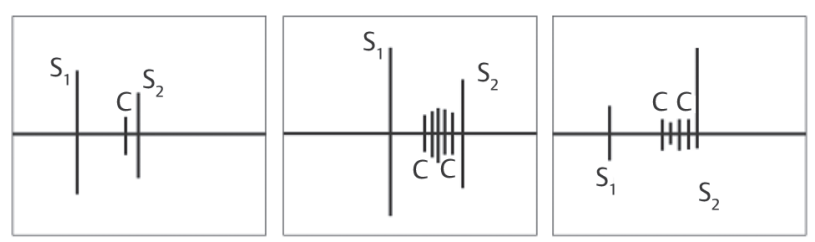

Fig. 10 Multiple clicks in mitral valve prolapse.

Table 7. Physiological maneuvers and their effect on midsystolic click in MVP

\begin{tabular}{|l|l|}
\hline Maneuver & $\begin{array}{l}\text { MVP click (timing, } \\
\text { intensity, duration) }\end{array}$ \\
\hline Positional changes & Earlier and louder \\
\hline \multicolumn{1}{|c|}{ Standing } & $\begin{array}{l}\text { Delayed and softer, may } \\
\text { disappear }\end{array}$ \\
\hline $\begin{array}{l}\text { Poising/squatting/leg } \\
\text { tion of AF }\end{array}$ & Delayed and soft \\
\hline \begin{tabular}{l} 
Valsalva \\
\hline Strain phase
\end{tabular} & Earlier and loud \\
\hline \multicolumn{1}{|c|}{ Overshoot phase } & Delayed and soft \\
\hline $\begin{array}{l}\text { Amyl nitrate inhalation/ } \\
\text { nitroglycerine }\end{array}$ & Earlier and louder \\
\hline Isometric exercise & Delayed and soft \\
\hline $\begin{array}{l}\text { Phenylephrine/maneuvers } \\
\text { which increased blood pressure }\end{array}$ & Delayed and soft \\
\hline
\end{tabular}

Abbreviations: AF, atrial fibrillation; MVP, mitral valve prolapse; PVC, premature ventricular contraction.
Differential diagnosis: Click of MVP must be distinguished from an aortic ejection click ( - Table 8).

Systolic clicks of TVP: Isolated TVP is a rare occurrence and is associated with a nonejection systolic click of right heart origin like as in MVP.

Systolic click of Ebstein's anomaly: An early sharp sound is heard in early systole, designated as the "sail sound" of Ebstein's anomaly. This occurs when the large sail-like anterior tricuspid valve leaflet has reached the maximum limit of systolic excursion. It occurs just after the peak of the $\mathrm{C}$ wave in the jugular venous pressure (JVP).

\section{Opening Snap (OS)}

It is an additional sound heard in the diastole ${ }^{1-4}(\neg$ Fig. 13). It is described as an early diastolic, high-pitched sound, which is associated with opening of the mitral and/or tricuspid valve.

History ${ }^{14,15}$ : OS was first described in mitral stenosis (MS) patients by Bouillaud (1835) and later by Durozier (1862) as asynchronism of pulmonary and aortic valve closure, who compared this to the syllables "ffou-ta-ta-rou." Guttman in 1872 and later Sansom (1881) suggested that this sound was due to vibration at the stenosed mitral valve itself. Finally, it was Rouches in 1888 who introduced the present nomenclature of "claquement d'ouverture de la mitrale" or OS of the mitral valve to describe this sound. According to him, this sound was produced by sudden tensing of the stenosed mitral valve by the blood passing from the left atrium to the left ventricle. Although other hypothesis have been proposed, it was finally concluded to be the mechanism by Margolies and Wolferth (1932) after a detailed clinical and phonocardiographic study of this sound.

Mechanism of OS: OS results from abnormal audible opening of diseased mitral or tricuspid valves. Abrupt opening of the valves to its maximum results in sudden tensing of the abnormal leaflets and subvalvular apparatus, producing this crisp sound. This is seen in early diastole when the ventricle is relaxed sufficiently to allow the atrial pressure to be effective. Mobility of the valve contributes to its genesis. An OS is absent when the valve is heavily calcified and immobile. An OS snap can also be produced in the absence of diseased valves, due to increased blood flow, especially across the mitral valve into normal LV.

\section{Conditions with OS}

1. Diseased atrioventricular valves.

a. MS

b. Tricuspid stenosis (TS)

2. Normal atrioventricular valves, but excess blood flow from mitral valve into LV

a. VSD

b. Patent ductus arteriosus (PDA)

c. Mitral regurgitation (MR) 

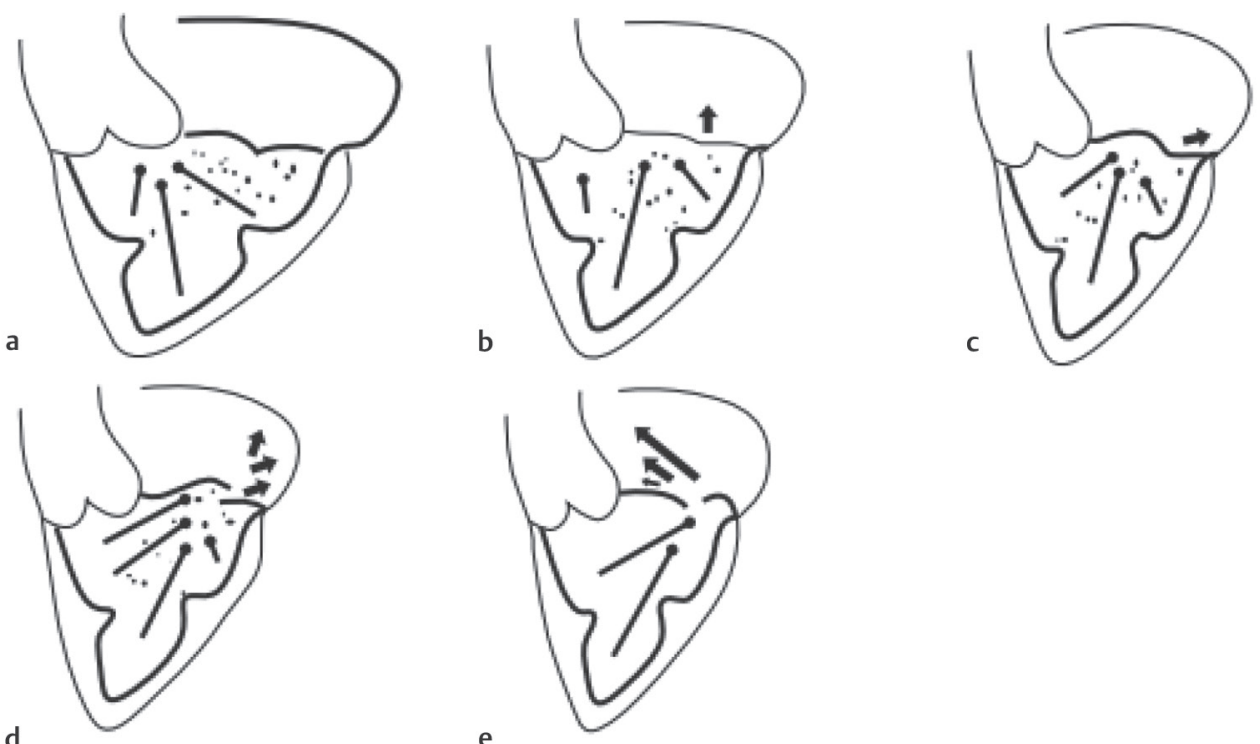

Fig. 11 Relation between LV size/volume and degree of MVP. (a). Prolapse of mitral leaflets does not occur at the onset of systole. (b-c). Onset of prolapse of leaflets. (d). Occurrence of click at the critical point of LV size where there is no coaptation of leaflets and prolapse is to the maximum. (e) Click is followed by murmur. Abbreviations: LV, left ventricle; MVP, mitral valve prolapse.

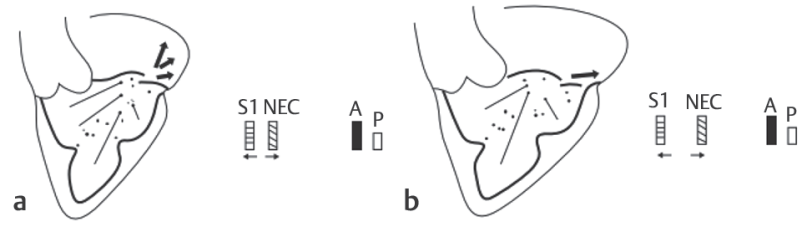

Fig. 12 Relation between LV volume and occurrence of midsystolic click in MVP. (a): Above figure shows early occurrence of ejection click, close to S1 when LV volume is small. (b): Figure below shows late occurrence of ejection click when LV volume is increased. Abbreviations: LV, left ventricle; MVP, mitral valve prolapse.

Table 8. MVP click versus aortic ejection click

\begin{tabular}{|l|l|l|}
\hline & Click of MVP & $\begin{array}{l}\text { Aortic ejection } \\
\text { click }\end{array}$ \\
\hline Timing & Mid to late systole & Early systole \\
\hline $\begin{array}{l}\text { Relation to carotid } \\
\text { pulse }\end{array}$ & $\begin{array}{l}\text { Happens after the } \\
\text { beginning of the } \\
\text { upstroke }\end{array}$ & $\begin{array}{l}\text { Occurs with the } \\
\text { beginning of the } \\
\text { carotid upstroke }\end{array}$ \\
\hline
\end{tabular}

Abbreviation: MVP, mitral valve prolapse.

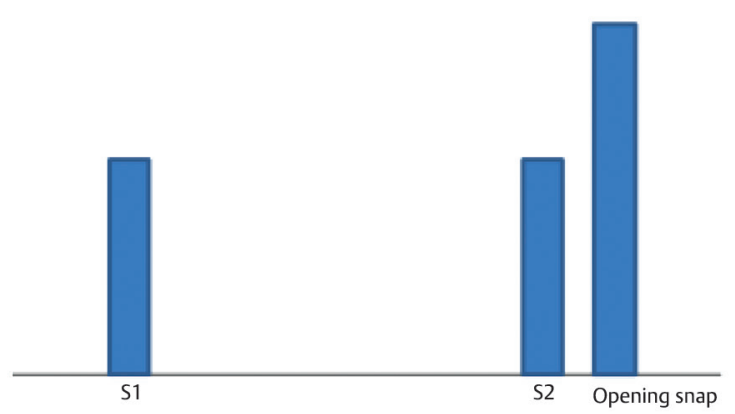

Fig. 13 Opening snap.
3. Rare conditions wherein a mitral OS is heard in the presence of a normal mitral valve are ${ }^{16}$ :

a. Tricuspid atresia with a large atrial septal defect (ASD).

b. Idiopathic second- and third-degree heart block.

c. Thyrotoxicosis.

d. Tetralogy of Fallot occurring after a Blalock-Taussig procedure.

\section{Characteristic Features of OS}

- Sharp, high-pitched, crisp sound heard with the diaphragm of the stethoscope.

- Best heard in the supramammary area between the apex and the LLSB, but it has a wider area of radiation. It is loudest in the fourth left interspace, occasionally in the third, and slightly above and to the right of the area in which the diastolic murmur is best heard (i.e., the supramammary area). It is next best heard at the apex, left sternal border, and at the base of the heart in the aortic position, with the least common location being the pulmonary area.

- Usually heard 40 to 120 milliseconds after the second heart sound, it precedes the mid-diastolic murmur by a short interval. The S2-OS interval is influenced by the heart rate (HR) and tends to shorten with tachycardia. During atrial fibrillation (AF) and sinus arrhythmias, the interval duration depends on the length of the preceding cardiac cycle.

Best audible in recumbent position. Exercise can augment its audibility by increasing the HR as OS is louder at higher rates.

\section{Clinical Significance}

Mitral stenosis (MS) ${ }^{17-19}$ :

- Mitral OS followed by a mid-diastolic murmur is characteristic of MS and not a flow rumble across a nonstenotic valve. 
- Presence of a crisp OS suggests that the mitral valve leaflets are mobile and pliable.

- It softens or disappears as the leaflets become ore calcific and immobile.

- The S2-OS interval helps in assessment of the left atrial pressure and severity of MS.

- In severe MS, because of higher left atrial pressure, the transmitral gradient develops immediately after mitral valve opening (MO), resulting in an OS almost just after $\mathrm{S} 2$.

- In mild mitral stenosis, the OS occurs later in diastole due to delayed transmitral gradient.

- In addition, in severe MS, the OS is followed by a longer murmur, as it takes more time for blood to pass through the stenotic mitral valve and for the pressure gradient to dissipate once the mitral valve opens.

- Intervals < 70 milliseconds suggest severe MS, and > 100 milliseconds are compatible with mild obstruction.

- An A2-OS interval of $\geq 80$ milliseconds indicates the left atrial mean pressure is normal ( 9 to $12 \mathrm{~mm} \mathrm{Hg}$ ).

- An A2-OS interval of $<60$ milliseconds indicates a markedly elevated left atrial mean pressure (25 to 36 $\mathrm{mm} \mathrm{Hg}$ ).

- When the A2-OS interval was 60 to 80 milliseconds, there was an overlap of mean pressure value (12 to 25 $\mathrm{mm} \mathrm{Hg})^{20}$

- Reduction of $<20 \%$ of the interval on exercise suggests an increase of $<35 \%$ left atrial mean pressure.

- Whereas a decrease of the A2-OS interval $>30 \%$ is associated with $>40 \%$ increase of the left atrial mean pressure.

OS is a useful diagnostic sign in MS, especially when other signs have been missed on casual examination. Its presence prompts for a more thorough search for the latent mid-diastolic murmur. Absence of OS in a confirmed case of MS indicates either

a. mild MS; b. calcified immobile valve c. associated significant MR.

Tricuspid Stenosis (TS): OS in TS was first described by Rivero Carvallo (1952-53) ${ }^{21}$ as a sound from the diseased tricuspid valve and defined as "chasquido de apertura de la trictspide." The sound is similar in almost all respects to the OS of the mitral valve except for its area of audibility. It is shorter in duration, occurs earlier and relatively lower pitch than the mitral OS, and best heard over the xiphisternum and right lower end of the sternum ${ }^{22}$

Differential diagnosis: OS could be confused for split second heart sound or third heart sound ( - Table 9, - Fig. 14).

The time intervals of opening snap and its mimics play an important role in identifying its character and is depicted in -Fig. 14.

The sequence of events would be split S2, OS, and then S3 in view of occurrence and intervals (-Fig. 15).

The OS and second component of split-second sound can be differentiated clinically, based on the best audible site and interval. Deep breathing technique is of great value, especially since both the sounds are heard. Differentiation of opening snap from S3 rarely poses a dilemma in clinical reality.

-Fig. 16 summaries the confusion among the additional sounds around first and second heart sound in practice.

\section{Pericardial Knock ${ }^{1-4}$}

- It is a high-pitched early diastolic sound, characteristic of constrictive pericarditis. Previously referred to a pericardial protodiastolic sound.

- It is an early sharp S3, which occurs 100 to 120 milliseconds after S2 (- Fig. 17).

- Best heard with the diaphragm of the stethoscope at the LLSB.

- It is rarely palpable.

- It occurs at the trough of Y descent of JVP.

Mechanism $^{23}$ : Pericardial knock is heard when the stiff and thickened pericardium causes sudden cessation of ventricular filling during early diastole. When the expanding ventricles achieve the limits imposed by the nondistensible thickened pericardium, there is a sudden deceleration of diastolic filling. This produces a sharp sound known as the pericardial knock. The LV filling pressure curve showed a rapid filling period lasting for 30 to $40 \%$ of total diastole, followed by a sudden and abrupt plateau, which persisted up to the end of the diastole. Two hypotheses for genesis of the sound has been suggested.

Table 9. Differential diagnosis of opening snap

\begin{tabular}{|l|l|l|l|}
\hline Clinical feature & OS & Split S2 & Third heart sound \\
\hline Interval between the sound & Longer (40-120 milliseconds after A2) & $\begin{array}{l}\text { Shorter (30-50 } \\
\text { milliseconds) }\end{array}$ & $\begin{array}{l}\text { Much longer (160-240 millisec- } \\
\text { onds after A2) }\end{array}$ \\
\hline Area best heard & Between the LLSB and apex & Pulmonary area & A little internal to mitral area \\
\hline Character & High-pitch-loud and sharp & Softer & Low-pitched \\
\hline Effect of respiration & $\begin{array}{l}\text { None on interval. Intensity diminished in } \\
\text { inspiration }\end{array}$ & $\begin{array}{l}\text { Split widens in } \\
\text { inspiration }\end{array}$ & None on interval \\
\hline Conditions & MS/TS & Physiological & Physiological/MR/LVF \\
\hline
\end{tabular}

Abbreviation: LLSB, left lower sternal border; LVF, left ventricular function; MR, mitral regurgitation; MS, mitral stenosis; OS, opening snap; TS, tricuspid stenosis. 


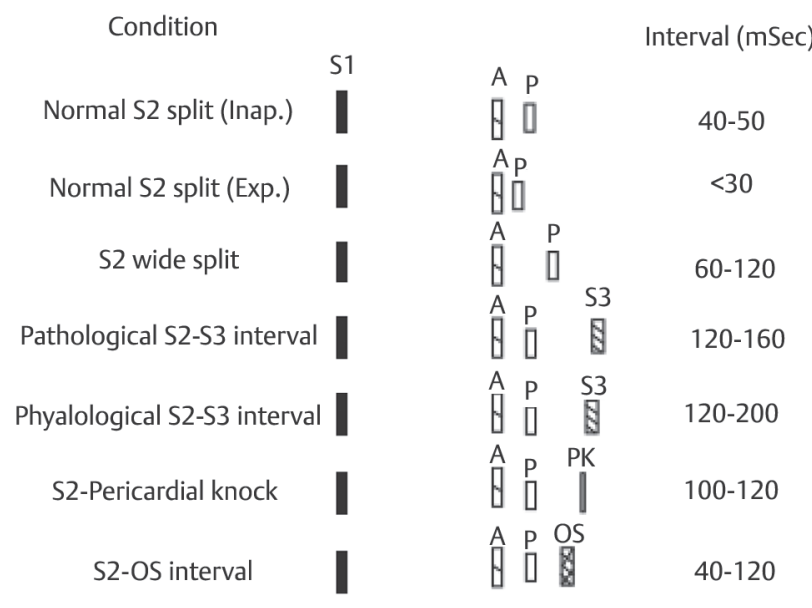

Fig. 14 Occurrence of time intervals of opening snap and its mimics.

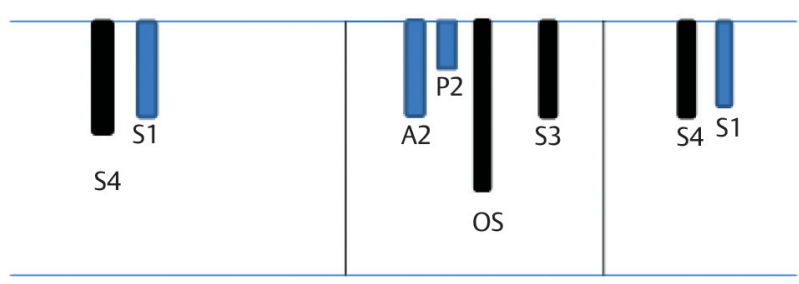

Fig. 15 Sequence of events in relation with opening snap.

Confusion around
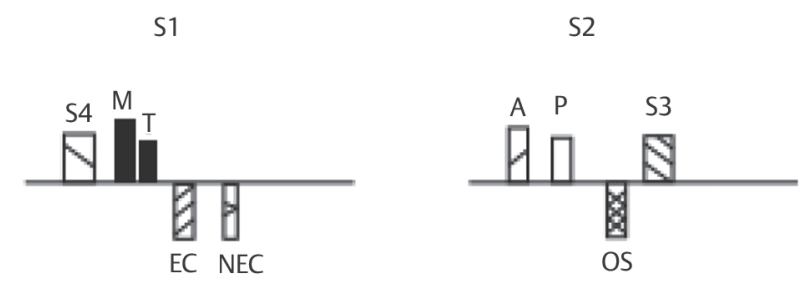

Fig. 16 Additional sounds causing confusion around S1 and S2.

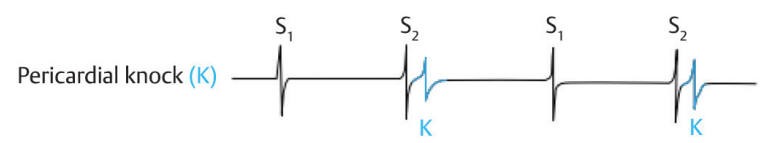

Fig. 17 Pericardial knock.

a. Water hammer effect-sudden deceleration of rapid filling blood into the ventricle sets into vibration the chamber blood, ventricular walls, valves, and pericardium (like ventricular S3 gallop).

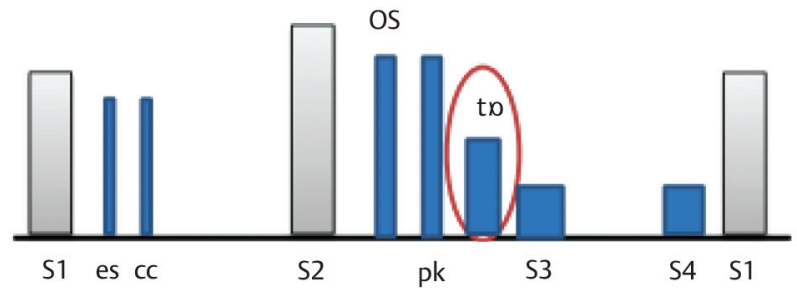

Fig. 18 Tumour plop.

b. Sail-flop phenomenon-Sudden tautening of the pericardium sets into vibration the chamber blood, walls and valves, producing the pericardial knock (like OS of MS or EC of AS).

\section{Differential Diagnosis}

S3 gallop is the most common differential diagnosis. A pericardial knock occurs closer to the S2 than S3 gallop, which occurs 100 to 200 milliseconds after S2. Pericardial knock is of higher pitch and louder than S3.

\section{Tumour Plop ${ }^{1-4}$}

Early diastolic low-pitched sound heard just after S2 (-Fig. 18). It is heard 80 to 150 milliseconds after the second heart sound. It may or may not be followed by a diastolic murmur. It is heard in left atrial myxoma.

\section{Differential Diagnosis}

- S3 gallop-timing and frequency may be indistinguishable.

- OS of MS-OS is a high-pitched sound in contrast to the low-pitched tumor plop.

- Split S2-single S2 followed by a tumor plop may mimic a split S2. However, tumor plop is a transient diastolic sound which disappears as one moves the stethoscope to the pulmonic area. If two sounds are heard at the pulmonic area, it is split S2.

Mechanism ${ }^{24}$ : When the phonocardiographic timings of the tumor plop was correlated with the echocardiographic motion pattern of the cardiac mass, it was noticed that the sound occurred when the diastolic forward motion of the mass was halted into the ventricle. Various hypotheses for generation of the sound have been suggested.

- It is the result of quick diastolic movement of the mass into the ventricle and its impact on the ventricular septum and ventricular wall.

- Tumour obstruction of the mitral orifice along with high velocity across it causes the sound

- Sudden tensing of the tumor stalk and impact on the interventricular septum and right ventricular posterior wall.

Occurrence of tumor ploy requires presence of a large mass and/or a long tumor stalk. The mass can move into the ventricle in two stages-early diastolic passive filling stage and late atrial contraction stage; hence, two sounds 
can also be heard, that is, early diastolic and late diastolic sounds.

\section{Other Diastolic Sounds}

1. Vegetation plop ${ }^{25}$ : an early diastolic sound occasionally heard in endocarditis. This sound is produced when a large vegetation over the mitral valve moves into the LV during early diastole.

2. High-frequency early diastolic sounds are occasionally heard in the following:

a. MVP-sound is related to rapid movement of the prolapsed MV into LV before opening of the mitral valve.

b. Hypertrophic cardiomyopathy-sound is related to contact of the anterior mitral leaflet (AML) with the interventricular septum (IVS) in early diastole, especially in patients with small LV cavity.

c. Severe MR due to ruptured chordae.

\section{Pericardial Friction Rub ${ }^{1-4}$}

Superficial, scratch or grating sound is a hallmark of pericardial inflammation. It is heard in acute viral pericarditis and Dressler syndrome (24-72 hours after acute myocardial infarction $[\mathrm{MI}])$.

Mechanism: It is the result of friction between the parietal and visceral layers of the inflamed pericardium. It occurs during the maximal movement of the heart within the pericardial sac.

\section{Characteristic Features ${ }^{26-30}$}

- Scratchy/leathery/grating sound-like the two pieces of sandpaper rubbing together. Loud enough to mask other cardiac murmurs.

- May present as a soft blowing murmur and confuse with other cardiac murmurs.

- Best heard with the diaphragm of the stethoscope.

- Best heard with firm pressure of the diaphragm during held inspiration and in leaning forward position or leaning over position ( - Fig. 19)

- May be localized or widespread and best heard at the lower sternal border.

- Although synchronizes with the heartbeat, it does not strictly correlate with the systole or diastole.

- It has three components-atrial systole, ventricular systole, and rapid filling phase of the ventricle ( - Fig. 20)

- However, it may present as one component or two.

- The order of the most audible component is ventricular systole $>$ atrial systole $>$ rapid filling phase.

- The three-component sound in heard in less than $50 \%$ cases.

- Usually a to-and-fro rub is heard representing the ventricular systole and atrial systole.

- Single component is rare and heard in myocarditis, following transmural MI, resolving stage of pericarditis, and in the presence of atrial fibrillation.
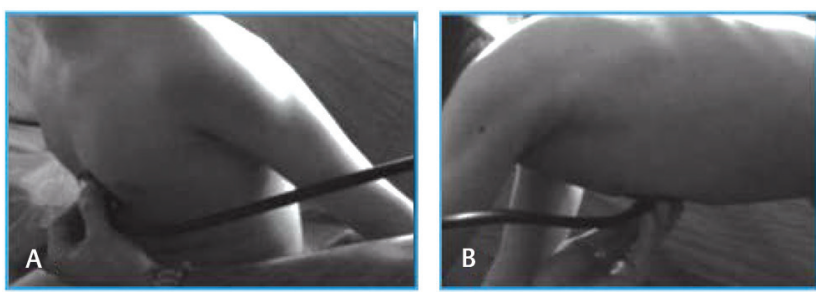

Fig. 19 Best position to auscultate for pericardial friction rub.

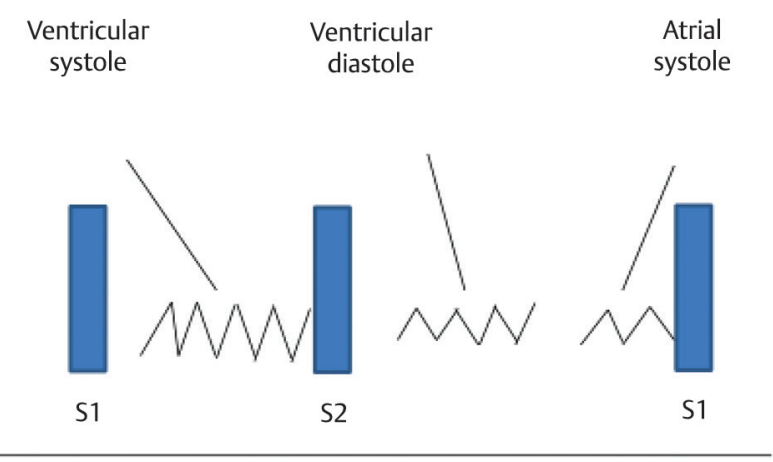

Fig. 20 Components of friction rub.

Inconsistency is a striking feature of pericardial rub. It is usually transitory or evanescent, persisting for few hours or days. Its intensity, character, duration, and site of audibility also varies over a period.

\section{Differential Diagnosis}

1. Pleural rub (-Table 10).

2. Systolic or to-and-fro murmur (-Table 11).

3. Means-Lerman scratch in thyrotoxicosis-a to-and-fro high-pitched sound heard over the left second space

4. Hamman's sign/mediastinal crunch-acute mediastinal emphysema, usually postopen heart surgery.

5. Sail sound in Ebsteins's anomaly.

6. Pacemaker heart sound-twitching of the intercostal muscles or the diaphragm during artificial pacing.

7. Pleuropericardial rub: A pleuropericardial rub, resulting from friction between the inflamed pleura and parietal pericardium, can often be confused for a pericardial rub. This happens in dry pleurisy when the anterior margin of the lung is affected. The adjacent heart is involved, and the friction rub now confronts cardiac rhythm rather than the respiratory movements. This movement occurs with beating of the heart and disappears with deep respiration or cessation of breathing.

8. Movement of transvenous pacing lead or balloon floatation catheter across the tricuspid valve produces an early systolic superficial scratching sound that may be confused for a single component friction rub. These sounds usually disappear with alteration of the patient's position

9. Inadvertent entry of air into the RV cavity and its movement with RV systole and diastole produces a slushing 
or crunching sound (mill wheel murmur) which mimics pericardial rub.

10. Swallowing sounds produced by vibration of vocal cords during swallowing.

\section{Clinical Significance ${ }^{31-35}$}

1. Acute MI-a pericardial rub after acute MI suggests a transmural infarction and a contraindication to anticoagulation. It is responsible for persistent pain after MI and a reason for pyrexia after acute MI. Prompt relief is seen with steroids.

2. Rheumatic carditis-suggests pan carditis and response with steroids.

3. Postheart surgery-suggests pericardiotomy pericarditis.

4. Chronic renal failure- intensification of dialysis

5. Infective endocarditis-myocardial abscess/ring abscess.

6. Liver abscess-extension into the pericardium.

Table 10. Differentiating features between pleural and pericardial rub

\begin{tabular}{|l|l|}
\hline Pleural rub & Pericardial rub \\
\hline $\begin{array}{l}\text { Correlates with respiratory } \\
\text { movements }\end{array}$ & $\begin{array}{l}\text { Does not correlate with respira- } \\
\text { tory movements }\end{array}$ \\
\hline $\begin{array}{l}\text { Grossly affected by respiration } \\
\text { and cessation of breath- } \\
\text { ing-heard in inspiration. } \\
\text { Disappears with expiration } \\
\text { and breath-holding }\end{array}$ & $\begin{array}{l}\text { Not affected-heard in both } \\
\text { phases of respiration and even } \\
\text { after cessation of breathing }\end{array}$ \\
\hline $\begin{array}{l}\text { Independent of cardiac } \\
\text { rhythm }\end{array}$ & Correlated with cardiac rhythm \\
\hline $\begin{array}{l}\text { Pain on the lateral aspect of } \\
\text { chest wall }\end{array}$ & $\begin{array}{l}\text { Pain usually in the central loca- } \\
\text { tion of rib cage }\end{array}$ \\
\hline $\begin{array}{l}\text { Intensity increased with } \\
\text { pressing of diaphragm of } \\
\text { stethoscope over the affected } \\
\text { chest wall }\end{array}$ & $\begin{array}{l}\text { No such variation or accentua- } \\
\text { tion seen }\end{array}$ \\
\hline
\end{tabular}

Table 11. Differentiating features between pericardial rub and cardiac murmur

\begin{tabular}{|l|l|l|}
\hline Quality & Pericardial rub & Cardiac murmur \\
\hline Timings & $\begin{array}{l}\text { Scratch/grating/ } \\
\text { leathery }\end{array}$ & $\begin{array}{l}\text { Blowing/rumbling/ } \\
\text { musical }\end{array}$ \\
\hline Site of audibility & Systolic or diastolic & Systole-diastole \\
\hline Radiation & Nil & $\begin{array}{l}\text { Typical auscultatory } \\
\text { areas }\end{array}$ \\
\hline Constancy & No & Yes \\
\hline Duration & Evanescent & Yes \\
\hline $\begin{array}{l}\text { Firm pressure with } \\
\text { diaphragm }\end{array}$ & Accentuates & No change \\
\hline $\begin{array}{l}\text { Effect of } \\
\text { respiration }\end{array}$ & $\begin{array}{l}\text { Accentuated with- } \\
\text { held inspiration }\end{array}$ & $\begin{array}{l}\text { Not much except } \\
\text { right sided events }\end{array}$ \\
\hline Position & $\begin{array}{l}\text { Accentuate with } \\
\text { leaning forward } \\
\text { posture }\end{array}$ & Does not vary \\
\hline
\end{tabular}

Abbreviation: LLSB, lower left sternal border.
7. Malignancy-pericardial involvement.

8. Patients in shock heart failure-look for cardiac tamponade.

9. Fever with septic foci-pyogenic pericarditis.

10. Fever of unknown origin-tuberculosis.

Hamman's crunch ${ }^{36,37}$-Multiple crunchy sounds heard when the heart beats against the air-filled tissues. These precordial crackles correlate with the heartbeat and not respiration.

They are seen in the following:

Pneumopericardium-postcardiac surgery, postresuscitation, or postpericardiocentesis

Pneumomediastinum-spontaneous mediastinum emphysema or Boerhaave syndrome.

\section{Prosthetic Sounds ${ }^{1-4}$}

The opening and closing of prosthetic valves produce sounds which may vary in intensity and timing according to the type and design of the valve, patient's rhythm, and hemodynamic status. Prosthetic sounds are the result of valve component motion or abnormal flow patterns. These sounds are louder, of higher frequency than normal sounds, and usually described as "clicky" quality. They may be single or multiple.

\section{Characteristics Features}

- A metallic click before the carotid pulse (occurs in diastole after S2) is an auscultatory sign of mitral valve replacement, and a click just after the carotid pulse (occurs in systole, after S1) is heard in aortic valve replacement (-Fig. 21).

- A mitral prosthetic sound is heard louder in the mitral area and an aortic prosthetic sound over the aortic area.

Classical click-Loud, high-frequency metallic closing sounds are typically heard with tilting disc and bileaflet
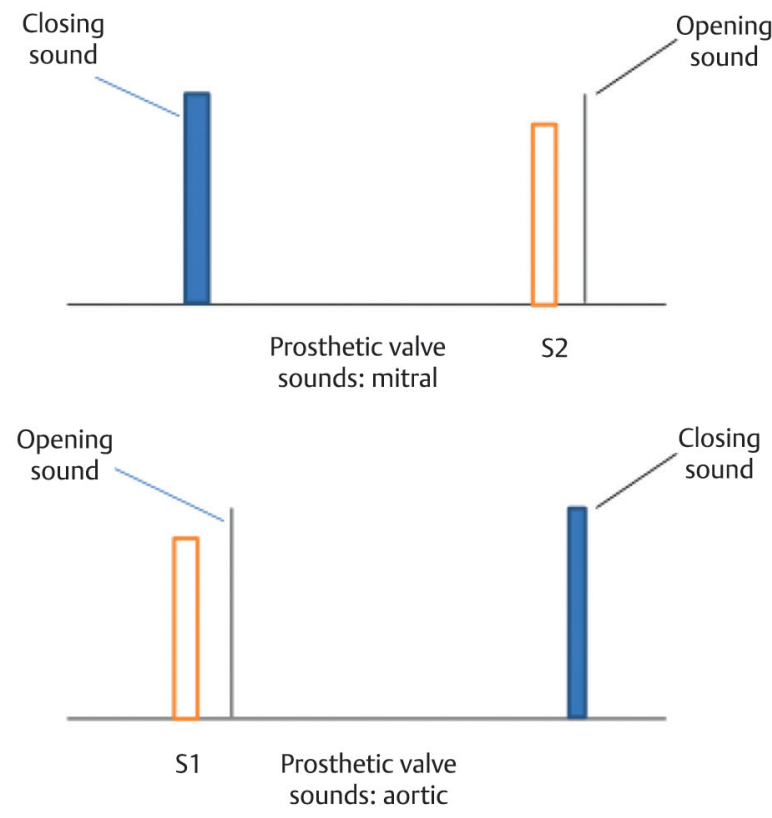

Fig. 21 Mitral and aortic prosthetic sounds. 
valves. They can be heard even without a stethoscope. A soft opening sound may also be heard.

Ball and caged valves (Star-Edwards)-They have easily audible opening and closing sounds. These sounds are distinct, high-pitched prominent sounds (relatively low-pitched compared with disk and leaflet valves) which can be easily distinguished from normal heart sounds. Both the opening and closing sounds are of equal intensity. The sounds can be very loud, depending on the prosthetic model and composition of the ball. The sounds correspond to the maximal excursion of the ball and its subsequent seating.

Classical clicks are not heard with tissue valves; instead, low-pitched sounds different from the normal heart sounds are heard

Auscultatory features: Auscultatory features ${ }^{38-40}$ of different prosthetic valve in mitral and aortic position are mentioned in - Table 12 .

Table 12. Auscultatory features of different prosthetic valves

\begin{tabular}{|c|c|c|}
\hline $\begin{array}{l}\text { Type and } \\
\text { design of valve }\end{array}$ & Mitral area & Aortic area \\
\hline $\begin{array}{l}\text { Ball valves (e.g., } \\
\text { Starr-Edwards) }\end{array}$ & $\begin{array}{l}\text { Opening sound } \\
\text { (MO) heard in } \\
\text { diastole } \\
\text { MO louder than } \\
\text { closing sound (MC) } \\
\text { A2-MO inter- } \\
\text { val 70-110 } \\
\text { milliseconds }\end{array}$ & $\begin{array}{l}\text { Opening sound (AO) } \\
\text { heard in systole } \\
\mathrm{AO} \text { louder than clos- } \\
\text { ing sound }(\mathrm{AC}) \\
\mathrm{S} 1-\mathrm{AO} \text { is } 70 \\
\text { milliseconds }\end{array}$ \\
\hline $\begin{array}{l}\text { Tilting disc } \\
\text { valves (e.g., } \\
\text { Medtronic-Hall) }\end{array}$ & $\begin{array}{l}\text { MO is soft and may } \\
\text { not be audible. } \\
\text { A2-MO 50-90 } \\
\text { milliseconds }\end{array}$ & $\begin{array}{l}\text { AO is soft and may } \\
\text { not be audible } \\
\mathrm{S} 1-\mathrm{AO} \text { is } 40 \\
\text { milliseconds } \\
\mathrm{AC} \text { is louder than } \mathrm{AO}\end{array}$ \\
\hline $\begin{array}{l}\text { Bileaflet valves } \\
\text { (e.g., St. Jude) }\end{array}$ & - & 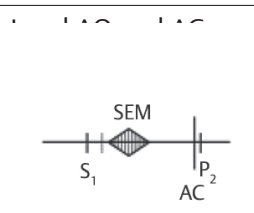 \\
\hline $\begin{array}{l}\text { Bioprosthetic } \\
\text { valves }\end{array}$ & $\begin{array}{l}\text { MC louder than } \mathrm{MO} \\
\mathrm{MO} \text { audible in } 50 \% \\
\mathrm{~A} 2-\mathrm{MO} \text { interval } 100 \\
\text { milliseconds }\end{array}$ & $\begin{array}{l}\text { AC louder than } \mathrm{AO} \\
\mathrm{AO} \text { may be absent } \\
\mathrm{S} 1-\mathrm{AO} \text { interval } \\
30-80 \text { milliseconds }\end{array}$ \\
\hline
\end{tabular}

Abbreviations: AC, aortic closing; AO, aortic opening; MC, mitral closing; $\mathrm{MO}$, mitral opening.
Note: TTK Chitra ${ }^{41}$ is a low-cost, high-quality single leaflet tilting disc. In contrast to other disk valves, valve closing sounds are soft and dull due to the use of ultrahigh-molecular weight polyethylene disc; hence, less disturbing in a lean person

Of the commonly used mechanical valves, the sounds associated with Duromedics Edwards (33.5 dB) and BjörkShiley Monostrut valves ( $31 \mathrm{~dB}$ ) are significantly louder than St Jude Medical (24 dB) and Carbomedics $(25 \mathrm{~dB})$ valves. ${ }^{42,43}$

\section{Clinical Significance}

Muffled or absent normal prosthetic sound is a clue to valve failure or thrombosis.

\section{Abnormal Prosthetic Sounds ${ }^{1-4,44-46}$}

Ball and caged valves: Both the opening and closing sounds are loud and easily audible. Multiple sounds are frequently heard in a normally functional ball valve.

Abnormal mitral prosthetic sounds-A normal mitral ball valve produces a very prominent opening click, corresponding to the nadir or 0 point of apexcardiogram. It follows the A2 by 0.07 to 0.11 seconds.

1. A2-mitral opening (MO) interval differs minimally from beat to beat even in AF.

a. A2-MO interval $<0.05$ seconds suggests prosthetic valve obstruction or severe MR.

b. A2-MO interval $>0.17$ seconds or a beat to beat alteration of the interval suggests abnormal interference with the poppet excursion-stuck valve.

2. Diminished mitral closing (MC) sound in conditions where the poppet has already assumed a closed position before the onset of ventricular isovolumic systole.

a. First-degree heart block.

b. Long R-R intervals.

3. Single prosthetic closing sound (MC) without and opening sound (MO)-

a. Premature ventricular beat-The poppet fails to open after a premature ventricular contraction (PVC), drifts to open position slowly during next diastole and is forcibly closed by the next ventricular contraction, producing a single closure sound.

Abnormal aortic prosthetic sounds:Normally, the ball proceeds to the apex of the cage at the point of LV-aortic opening (AO) pressure crossover. This produces a loud opening click which occurs approximately 0.07 seconds after S1. The ball may remain at the apex or midcage for the entire systole, resulting in production of multiple systolic clicks.

1. Increased intensity of both $\mathrm{AO}$ and aortic closing $(\mathrm{AC})$ sounds-

a. Tachycardia.

b. Anemia.

2. Diminished intensity of both AO and AC sounds-

a. Low-cardiac output state

3. Diminished AO (opening sound)-Normally, the amplitude ratio of $\mathrm{AO}$ to $\mathrm{AC}$ is $>0.5$. Reduction of this ratio or absence of appreciable AO is a sign of ball valve dysfunction. 
4. An early ventricular beat may be associated with an absent $\mathrm{AO}$, whereas a late ventricular beat may produce both $\mathrm{AO}$ and $\mathrm{AC}$ sounds.

Tilting disc valves:Normally, distinct closing sounds are heard. These sounds are high-pitched click-like sounds corresponding to the onset of valve closure. However, the opening sound may not be produced as the lightweight disk swings open without forcibly striking any resonant structure

Abnormal mitral prosthetic sound:Prosthetic opening sound (MO), corresponding to disk motion, is rarely heard, but a prominent $\mathrm{MC}$ is heard

Absent or diminished intensity of MC-

a. When disk seats early.

i. LV dysfunction.

ii. First-degree atrioventricular (AV) block

b. When disc movement is hindered.

i. Fibrosis.

ii. thrombosis.

Abnormal aortic prosthetic sounds: Distinct closing sound is heard. Diminution or absence of it is indication of prosthetic valve fibrosis, thrombosis or LV dysfunction.

Bileaflet Valve (St. Jude)

Abnormal aortic prosthetic sounds: Distinct opening sound (AO) is heard after the maximal opening of the valve leaflets, suggesting its origin to be due to turbulent flow and not the leaflets. In contrast, a prominent AC is heard corresponding to the leaflet closure.

Diminished or absent closing sound is a sign of valve dysfunction.

Acoustic characteristics in mitral position have not been described.

Tissue valves (Hancock, Carpenter-Edwards): Both closing and opening sounds are heard, much less prominent than with mechanical valves. Opening sound corresponds to abrupt halting of the opening motion of the leaflets. Closing sounds correspond to deceleration of blood column or due to leaflet contact. Closing sounds are much louder than opening sounds with bioprosthetic valves.

\section{Diminished or Absent Closing Sound is a Sign of Malfunction}

Ball variance is a term used to describe the physical changes in a ball valve, which results in changes in the intensity of the opening and closing sounds. It is related to specific model of the ball valve, which is rarely in use nowadays.

\section{Conclusion}

Change in the normal prosthetic sound is a sign of valve malfunction. Irrespective of the type of prosthetics valve, the closing sound is usually louder. A decreased intensity of this closing sound should suggest malfunction of the valve. However, malfunction can exist despite the presence of a normal sound. In such cases, Doppler echocardiography and cardiac catheterization are required to establish the diagnosis.

\section{Conflict of Interest}

None.

\section{References}

1 Craigie E, Smith D, Heart sounds. In: Braun Wald E, ed. Heart Disease: A Textbook of Cardiovascular Medicine. Philadelphia: W.B. Saunders

2 Shaver JA, Salerni R, Reddy PS, Normal and abnormal heart sounds in cardiac diagnosis. Part I, Systolic sounds In Current Problems in Cardiology. Chicago: Yearbook Medical Publishers,; 1985

3 Shaver JA, Leonard JJ, Leon DF, Auscultation of the Heart: Examination of the Heart, Part 4. American Heart Association; 1990

4 Leatham A, Auscultation of the Heart and Phonocardiography, 2nd ed. London: J and A Churchill; 1975

5 Hancock EW. The ejection sound in aortic stenosis. Am J Med 1966;40:569

6 Leech G, Mills P, Leatham A. The diagnosis of a non-stenotic bicuspid aortic valve. Br Heart J 1978;40(9):941-950

7 Flanagan WH, Shah PM. Echocardiographic correlate of presystolic pulmonary ejection sound in congenital valvular pulmonic stenosis. Am Heart J 1977;94(5):633-636 [PubMed]

8 Hultgren HN, Reeve R, Cohn K, McLeod R. The ejection click of valvular pulmonic stenosis. Circulation 1969;40(5):631-640

9 Leatham A, Vogelpoel L. The early systolic sound in dilatation of the pulmonary artery. Br Heart J 1954;16(1):21-33

10 Pickering D, Keith JD. Systolic clicks with ventricular septal defects. A sign of aneurysm of ventricular septum? Br Heart J 1971;33(4):538-539

11 Waider W, Craige E. First heart sound and ejection sounds. Echocardiographic and phonocardiographic correlation with valvular events. Am J Cardiol 1975;35(3):346-356

12 Ronan JA, Perloff JK, Harvey WP. Systolic clicks and the late systolic murmur; intracardiac Phonocardiographic evidence of their mitral valve origin. Am Heart J 1965;70:319-325

13 Leon DF, Leonard JJ, Kroetz FW, Page WL, Shaver JA, Lancaster JF. Late systolic murmurs, clicks, and whoops arising from the mitral valve. A transseptal intracardiac phonocardiographic analysis. Am Heart J 1966;72(3):325-336

14 Mounsey P. The opening snap of mitral stenosis. Br Heart J 1953;15(2):135-142

15 Alexander Margolis MD, Charles C, Wolfforth MD. The opening snap (Claquement d'ouverture de la mitrale) in mitral stenosis, its characteristics, mechanism of production and diagnostic importance. Am Heart J 1932;7(4):443-470

16 Millward DK, McLaurin, LP, Craige, E. Echocardiographic studies to explain opening snaps in presence of non-stenotic mitral valves. Am J Cardiol 1973;31(1):P64-70

17 Rouches FJ. MI.: Du Claquement d'ouverture de la mitrale. Thes6 de Paris, 1882

18 Mann DL, Zipes DP, Libby P, Bonow RO, Braunwald's Heart Disease: A Textbook of Cardiovascular Medicine, 10th ed. Philadelphia, PA, USA: Elsevier Saunders; 2018

19 Fuster V, Narula J, Harrington RA, Eapen ZJ. Hurst's the Heart, 14th ed. New York, NY, USA: McGraw-Hill Education; 2017

20 Delman AJ, Gordon GM, Stein E, Escher DJW. The second sound-mitral opening snap (A2-OS) interval during exercise in the evaluation of mitral stenosis. Circulation 1966;33(3): 399-403

21 Rivero-Carvallo JM. El diagnostico de la estenosis tricuspidea. Arch Inst Cardiol Mex 1950;20:1 
22 Kossmann CE. The opening snap of the tricuspid valve: a physical sign of tricuspid stenosis. Circulation 1955;11(3):378-390

23 Burgess TE, Le NN, Olds GS, Sullivan PD, Mansoor AM. Pericardial knock. BMJ Case Rep 2019;12(12):e233546

24 Buksa M, Haracić A. Late diastolic tumor "plop" in an asymptomatic case of right atrial myxoma. Med Arh 1999;53(2):77-79

25 Kalaria VG, Schwarz KQ, Eichelberger JP, Allen M. "Vegetation plop"-auscultatory findings in large mitral valve vegetation. Clin Cardiol 2000;23(4):291-292

26 Chahine J, Siddiqui WJ. Pericardial Friction Rub. [Updated 2020 Sep 5]. In: StatPearls [Internet]. Treasure Island (FL): StatPearls Publishing; 2020 Jan-. Available at: https://www.ncbi.nlm.nih. gov/books/NBK542284/. Accessed May 26, 2020

27 Imazio M, Gaita F, LeWinter M. Evaluation and treatment of pericarditis: a systematic review. JAMA 2015;314(14):1498-1506

28 Doctor NS, Shah AB, Coplan N, Kronzon I. Acute Pericarditis. Prog Cardiovasc Dis 2017;59(4):349-359 [Medline]

29 Adler Y, Charron P, Imazio M, [Guideline]ESC Scientific Document Group, et al; 2015 ESC Guidelines for the diagnosis and management of pericardial diseases: The Task Force for the Diagnosis and Management of Pericardial Diseases of the European Society of Cardiology (ESC)Endorsed by: The European Association for Cardio-Thoracic Surgery (EACTS) Eur Heart J 2015;36(42):2921-2964

30 Bach DS. 2015 ESC guidelines for pericardial disease. American College of Cardiology. Available at: https:// www.acc.org/latest-in-cardiology/ten-points-to-remember/2015/10/30/12/01/2015-esc-guidelines-for-the-diagnosis-and-management-of-pericardial-diseases. Accessed April 2, 2019

31 Soler-Soler J, Permanyer-Miralda G, Sagristà-Sauleda J. A systematic diagnostic approach to primary acute pericardial disease. The Barcelona experience. Cardiol Clin 1990;8(4): 609-620

32 Mastroianni A, Coronado O, Chiodo F. Tuberculous pericarditis and AIDS: case reports and review. Eur J Epidemiol 1997; 13(7):755-759

33 Lamas ES, Bononi RJ, Bernardes MVAA, et al. Acute purulent pericarditis due co-infection with Staphylococcus aureus and Mycobacterium tuberculosis as first manifestation of HIV infection. Oxf Med Case Rep 2019;2019(2):omy127
34 Tseng JR, Lee MJ, Yen KC, et al. Course and outcome of dialysis pericarditis in diabetic patients treated with maintenance hemodialysis. Kidney Blood Press Res 2009;32(1):17-23

35 Imazio M, Negro A, Belli R, et al. Frequency and prognostic significance of pericarditis following acute myocardial infarction treated by primary percutaneous coronary intervention. Am J Cardiol 2009;103(11):1525-1529

36 Hamman L. Spontaneous mediastinal emphysema. Bull Johns Hopkins Hosp 1939;64:1-21

37 Uda K, Matsushima T, Horikoshi Y, Hataya H. Hamman's sign in a patient with spontaneous pneumomediastinum. J Pediatr 2018;202:324

38 Smith ND, Raizada V, Abrams J. Auscultation of the normally functioning prosthetic valve. Ann Intern Med 1981;95(5):594-598

39 Butany J, Ahluwalia MS, Munroe C, et al. Mechanical heart valve prostheses: identification and evaluation (erratum). (erratum) Cardiovasc Pathol 2003;12(6):322-344

40 Butany J, Fayet C, Ahluwalia MS, et al. Biological replacement heart valves. Identification and evaluation. Cardiovasc Pathol 2003;12(3):119-139

41 Joshi LM, Singh Sk, Siddiqi S, et al. Critical evaluation of clinical results with TTK-Sree Chitra valve. IJTCVS 2005;21:15-17

42 Koertke H, Hoffmann-Koch A, Boethig D, et al. Does the noise of mechanical heart valve prostheses affect quality of life as measured by the SF-36 questionnaire? Eur J Cardiothorac Surg 2003;24(1):52-57, discussion 57-58

43 Pedersen TA, Johansen P, Hasenkam JM, Koerfer R, Koertke H, Nygaard $H$. Are sounds from mechanical heart valves equal for different valve types? J Heart Valve Dis 2008;17(5):579-582

44 Goldman ME. Echocardiographic doppler evaluation of prosthetic valve function and dysfunction. Adv Cardiol 2004; 41:179-184

45 RoudautR,SerriK,LafitteS.Thrombosisofprostheticheartvalves: diagnosis and therapeutic considerations. Heart 2007;93(1): 137-142

46 Kotler MN, Mintz GS, Panidis I, Morganroth J, Segal BL, Ross J. Noninvasive evaluation of normal and abnormal prosthetic valve function. J Am Coll Cardiol 1983;2(1):151-173 